\title{
Transformation Of Tradition Culture To Popular In The Show Of Gamelan Koromong Arts Cikubang Rancakalong Village Sumedang Regency
}

\author{
Rony Hidayat Sutisna ${ }^{1}$, Dadang Suganda ${ }^{2}$, Reiza D. Dienaputra ${ }^{3}$ \\ \{satyabuanapala.pgri2@yahoo.com ${ }^{1}$, dadang.suganda@unpad.ac.id ${ }^{2}$ \} \\ ${ }^{1}$ Doctoral candidate in Cultural Studies, Faculty of Cultural Studies, Padjadjaran University, Bandung, \\ Indonesia \\ 2,3. Faculty of Cultural Studies, Padjadjaran University, Bandung, Indonesia
}

\begin{abstract}
The purpose of this article is to discuss the process of cultural transformation from ritual to popular in the performance of gamelan koromong arts in Cikubang Village, Sumedang Regency, West Java. Gamelan koromong art is held once a year on the 14th of Maulud in the Islamic calendar year. This study analyzes the transformation process of gamelan koromong art that takes place in Cikubang from the old condition (tradition) to the new (popular) condition. Based on the context, koromong art functions is as ritual art only. But along with the changing times, the context experienced a process of transformation into a popular performing arts. This change in context also resulted in changes in the textual elements of the show. So the focus of the discussion in this article is on the factual conditions of gamelan koromong, the various changes that have taken place, and the factors that led to the change process.
\end{abstract}

Keywords: transformation, ritual, popular, koromong, gamelan.

\section{Introduction}

The purpose of this article is to discuss the process of cultural transformation from ritual to popular in the performance of gamelan koromong arts in Cikubang Village, Sumedang Regency, West Java. The main problem that will be examined in this study is cultural transformation. This research was conducted with the aim to reveal the factual conditions in the gamelan koromong art; reveal changes in aspects found in the in the gamelan koromong art from the concept of tradition to popular; reveal the factors causing structural changes in the gamelan koromong art; and reveal the impact of these changes in the presence of degraded values.

Gamelan music in West Java, Indonesia is divided into three groups namely gamelan pelog-salendro, gamelan degung, and gamelan renteng or often referred to as goong renteng. Gamelan koromong itself is used in ritual activities, including the type of gamelan renteng or goong renteng and is often used in ritual ceremonies related to agriculture.

According to Heins (1977) gamelan koromong is called as goong renteng or goong koromong is a type of traditional art that lives and develops in Cikubang Sumedang used in the context of traditional ceremonies to honor Dewi Padi which is presented in the form of a combination of music and dance, thus forming a complete performance. The tool used in gamelan koromong art is a set of gamelan called gamelan koromong which consists of bonang 
as many as 3 ancaks. Another Waditra is 2 pieces of kendang and goong. Based on Heins' statement, the gamelan koromong found in Cikubang is one of the arts which belongs to the type of goong jointly. This statement is reinforced by Sasaki (2007) that the gamelan koromong is described as an Islamic cultural artifact that is generally beaten in the month of Maulud. However, in the past, it was still that the Gamelan koromong was beaten in the rice harvesting ceremony in honor of Dewi Sri. The gamelan koromong is now considered sacred only because of its chairmanship and also because the community embraced Islam, so this art was beaten at the most sacred moment, namely in the month of Maulud and at the same time commemorating the Birthday of the Prophet Muhammad.

The initial description of the ensemble of gamelan music is found in the reliefs of the Borobudur temple in Central Java Province (Yudoyono, 1984). The meaning of the gamelan koromong according to Sasaki (2007) is identical to kolenang or bonang, so that the gamelan koromong may be considered as the gamelan renteng (goong renteng). From the rénténg group according to Atmadibrata (1987), until now at least some types of ancient gamelan in Sunda land have been known, namely; goong rénténg there are 9 devices, there are 4 koromong, monggang / balén there are 1 device, goong gedé has 1 device, sakati there are 2 devices, there are 2 devices. The rénténg group are: Goong rénténg Embah Bandong (Lebakwangi, Arjasari, Bandung), Goong rénténg Ciwaru (Ciuyah, Sumedang), Goong rénténg Babakan Ranjeng (Situraja, Sumedang), Goong rénténg Ngalambang Panggugah Manah (Sukamulya, Kuningan), Goong rénténg Talagamanggung (Talaga, Majalengka), Goong rénténg Cibeusi (Jalancagak, Subang), Goong rénténg Cireundeu (Bandung), Goong rénténg Cinangnang (Tambi, Indramayu), Goong rénténg Ki Sayu (Cirebon), Koromong Cikondang (Lamajang, Bandung), Koromong Cikubang (Rancakalong , Sumedang), Koromong Cileuweung (Darmaraja, Sumedang), Koromong Ujungjaya (Sumedang), Goong gedé Kampung Naga (Citorek, Lebak), Monggang / Carabalén (Jambansari, Ciamis), Sakati Kasepuhan (Cirebon), Sakati Kanoman (Cirebon), Degung Pangasih (Geusan Ulun Museum, Sumedang), Degung Kasepuhan (Cirebon).

The history of the existence of gamelan koromong in Cikubang Rancakalong village was obtained from the direct interviews with three koromong artists namely Nandang (48 years), Haris (69 years), and Odin (56 years). Apart from direct interviews with figures, information data was also obtained from several books and journal articles on the website. The books that discuss the gamelan koromong include: Laras in Sundanese Karawitan (Sasaki, 2007); Music In Java (Kunst, 1973); Sundanese Encyclopaedia "Nature, Humans, and Culture including Cirebon and Betawi Cultures (Rosidi, 2000); and Curriculum Vitae of the Kings of Sumedang Larang (Alam, 2008).

Sasaki (2008) said that the gamelan koromong Cikubang is one of the old gamelan whose repertoire is classified as intact because it is still often used and used by the community in the rice harvest ceremony. It was also said that the gamelan koromong was an artifact used in the spread of Islam. By the people now, this gamelan is sacred because of its age and its historical value. Rosidi, ed. (2000) describe this gamelan koromong as the goong rénténg. The mention of the goong rénténg is based on the position of the tool placed in line, in Sundanese it is called ngarénténg. Goong rénténg is the forerunner to the present gamelan. Jaap Kunst (1973) stated that the gamelan Cikubang is a gamelan Cikebo. In this book, there is no mention of the existence of the Cikubang village because the name Cikubang is a change from the name Cikebo. Recording the name of the gamelan Cikebo in a book published in 1973, long before it changed to Cikubang. Based on the results of the interview with Nandang, the change of name from Cikebo to Cikubang was around 1980. 
To give clarity in this article, the authors propose a theoretical framework relating to research. The main theory or grand theory used in examining the research problem in this article is the structuration theory proposed by Anthony Giddens. The structural theory is basically a social theory that seeks to find a middle ground regarding the duality of structures, namely structures that structure (old structures to new structures) that occur in the social sciences in general. There are two contrasting approaches, in looking at social reality. First, an approach that overemphasizes the dominance of structure and social power. Second, an approach that emphasizes individual aspects such as symbolic interactionism, which tends to subjectivism.

The basic of the structuration theory is the thought of Anthony Giddens in the sociocultural tradition. Giddens $(2010,26)$ said that two structural ideas, each of which relates to aspects of social relations. This aspect is understood through the introduction of differences between social structures and social systems. Gidden views dualism that occurs between agency-structures caused by structural-functional views, which are trapped in naturalistic views. He sees the naturalistic view of reducing actors in structure, then history is viewed mechanically, and not a contingency product of agent activity. Whereas phenomenological constructionism, according to the Giddens, always ends in subject imperialism. This Giddens framework is used to examine the various changes that have taken place in gamelan koromong art based on the involvement of agents, space and time which triggers the process of cultural transformation in various aspects of cultural forms within it.

Agencies, space and time that are the causes of change include the people themselves as members of the community who are scattered in various public spaces such as schools, communities, government, and so on. From each of these public spaces, media and information are scattered which at present are based on technology which from time to time slowly changes the outlook of life for some people. So that it influences the existence of gamelan koromong art which ultimately creates a transformation process in every aspect that exists both textual and contextual. As discussed by Hill (2011, 19-27) about the evolutionary process that occurred in Javanese gamelan. This evolutionary process points to the process of transforming Javanese gamelan culture from practice to function change. This means that both textually and contextually, this Javanese gamelan has undergone a fairly clear change from time to time. The causes of this change include the inclusion of media and information technology, the entry of training gamelan in the formal education path, the entry of gamelan performances in religious processes, and others.

In this article, the structuration theory proposed by Giddens is used as a grand theory to explore cultural phenomena and the relationship between agents and structures that occur in gamelan koromong art in the Cikubang Village, Rancakalong District, Sumedang Regency. Thus, the formulation of the problem that becomes the background in this research can be answered and discussed accurately and the validity of the results obtained can be accounted for. Understanding own culture according to the theory of Koentjaraningrat (1987: 85) is a whole system of ideas, actions, and human work in life. Culture is also used by each human being to learn. Its form is ideas, social behavior, and material artifacts. Ideas are cultural values which consist of the conceptions that live in the minds of most of the people about things they consider very noble. This value system that exists in a society is used as an orientation and reference in acting. The action itself is a social behavior that will eventually create material products in the form of cultural artifacts.

Koentjaraningrat also stated about the forming elements of culture based on Kluckhohn's thinking. These cultural elements are universal, namely language, scientific systems, social systems or social organizations, living or technological systems, livelihood systems, religious 
systems, and arts. These seven cultural elements are the principal analysis in revealing the factual conditions of the gamelan koromong art Cikubang Rancakalong District, Sumedang Regency, West Java. This analysis of the factual conditions becomes the mainland in observing the process of cultural transformation that occurs especially regarding changes in existing cultural values.

\section{Method}

Penelitian ini menggunakan pendekatan grounded theory yaitu desain riset kualitatif yang menjelaskan teori umum tentang proses, aksi dan interaksi (Creswell, 2014: 115), dengan metode studi kasus terhadap gejala atau fenomena perubahan aspek-aspek yang terdapat pada seni gamelan koromong di daerah Cikubang Kecamatan Rancakalong Kabupaten Sumedang. Metode penelitian ini adalah studi kasus atau sebuah studi terhadap peristiwa, yang melibatkan pelaku dalam adegan (setting) dengan memusatkan perhatian pada suatu kasus secara intensif dan rinci dalam pengumpulan dan analisis data. Studi kasus menurut Sukmadinata (2010: 64) merupakan suatu penelitian yang dilakukan terhadap suatu "kesatuan sistem". Kesatuan ini dapat berupa program kegiatan, peristiwa, atau sekelompok individu yang terkait oleh tempat, waktu, dan ikatan tertentu. Studi kasus adalah suatu penelitian yang diarahkan untuk menghimpun data, mengambil makna, memperoleh pemahaman dari kasus tersebut. Kasus dapat satu orang, satu kelas, satu sekolah, beberapa sekolah tetapi dalam satu lingkungan masyarakat tertentu.

This study used the grounded theory and design qualitative research describing his general theory of the process, action and interaction (Creswell, 2014: 115). The method used is a case study of the change aspect that are found on the local art "gamelan koromong" in Cikubang Village, Sumedang Regency, West Java. A method of this research is a case study or a study in the scene involving the (setting) with focused in a case by intensive and detailed in the collection and analysis of data. Sukmadinata (2010: 64) say a case studies is a research conducted for a unity or system. This unity could include the program, event, or a group of individuals related by place, time, and some tie. Case study is a research, directed to collect data of can one person, one school, several school but in a neighborhood a particular society.

\section{Results}

\subsection{Gamelan koromong Art}

The art of gamelan koromong is one of the ritual arts found in several regions in Sumedang Regency, West Java Province. But the focus of this article's object is on gamelan koromong art found in Cikubang Village, Rancakalong District. The gamelan koromong art is used in the context of ritual ceremonies to honor Dewi Padi, which is presented in the form of a combination of music and dance, thus forming a complete performance. The context of the performance of koromong art in Cikubang Rancakalong, Sumedang Regency was originally a ritual means to worship Dewi Sri, which is considered by the surrounding community as a goddess of fertility by bringing blessings to agricultural systems in this region. This myth is widely believed and developed in agricultural areas where people tend to act as farmers. This myth of believing in Dewi Sri is a manifestation that is carried out by farmers to change rice 
plants to be more beneficial, superior and produce a lot of crops. This is related to something that is considered supernatural, relations with nature, including discussing the origin of life (Wessing, 1990). This belief in myths does not only develop in regions in Indonesia, but its spread includes regions in Asia which on average cultivate the agricultural system as a living livelihood. In China, some research on folklore and trust in a myth are analyzed based on textual and contextual studies (Lihui, 2014). A myth has a considerable influence on people who believe it.

The tendency of traditional communities with an agricultural background is to believe in a patron who must be worshiped, as stated by Suwardi $(2013,158-170)$ who explained the agricultural processing system of the Prangkonan Hamlet, Purwosari, Girimulyo, Kulon Progo, Special Region of Yogyakarta by utilizing myths or trust in Dewi Sri who is believed to be able to maintain the balance of the cosmos. This myth is believed by the people as a god who maintains soil fertility. In Tuban, the belief in the myth of Dewi Sri is considered to bring abundant harvest and will eventually get a lot of money (Heringa, 1997). The concept and spiritual mindset that is based on the view of Javanese cosmology, then applied to the farming system turns out to bring about the fertility and well-being of the surrounding community.

Regarding the trust of the Cikubang community towards Dewi Sri, the authors analyzed using theories about Sundanese cosmology. The results of the discussion of Sundanese cosmology describe the relationship of the syncretic patterns of the Cikubang community to occult matters including belief in ancestral spirits and belief in Dewi Sri.

The Sundanese cosmological theory proposed by Suryalaga (2003) is more of an essential meaning about the problem of cash delay, its about kasundaan. His thinking is a means for digging, forgiving, and applying cultural wisdom, especially Sundanese culture in the spiritual life of the Sundanese people. Buana Panta Panta is a term that is carried from the level of Sundanese cosmology, and the way or way in finding its essential meaning using Rawayan Jati. Rawayan Jati is a whole process of the existence of human beings and the universe ranging from physical, psychological, spiritual, and spiritual. Sundanese cosmology consists of four main elements, namely the relationship between humans and humans, humans with nature, humans with the unseen, humans with their God.

The study of Sundanese cosmology is reinforced by the statement of Sumardjo (2006) about the life of Sundanese people in general which describes a system that regulates the pattern of worship to the Creator. These patterns of worship are clearly structured and can be interpreted through various community activities, especially the Sundanese community. These patterns have two patterns, three patterns, and four patterns. Human and human relations, human relations with nature, and human relations with God are representations of these patterns.

A representation of the relationship between the two things is based on "Sundanese" human relations with the religious system of the Godhead that is adopted by the local community. In the performance of gamelan koromong art, as a ceremony of hormatan there is a leader to carry out the honor ceremony among themcalled Saehu for male and Pangibuan dancer leaders for female dancer leaders. Saehu is the one who carries out the ritual by dancing accompanied by five ritual songs and among them, the song in the first place is the song pamapag or keupat eundang. It needs to be underlined, how important the role of Saehu and pangibuan is in the performance of the koromong and tarawangsa ceremonies as honor ceremonies to Dewi Sri and ancestral spirits (karuhun) because a Saehu and pangibuan are movers, regulators, directors and promoters in this performance so that in the end it can be seen the work of Saehu and pangibuan with the success or failure of a performance. Here we can see there are two leaders in one "group", a phenomenon when a group or show here is led 
by two people at once. In reality, when one group is led by two people, there will be differences of opinion that can divide the unity. However, in this performance, two ritual leaders united. This signifies a dualistic relationship between men and women, a symbol of unification that causes new life, birth, and fertility.

Based on the description above, it appears that the old Sundanese cosmological concept is not only intended for knowledge solely about the structure of the universe dbut rather as a medium so that human life is clearly the ultimate goal, namely happiness and peace of life in the buana niskala and the eternal jatiniskala world. The concept of Sundanese cosmology is clearly visible in the structure of this Cikubang coromong performance. The belief in the existence of the heavenly realm which is the residence of Dewi Sri and the spirits of Karuhun is shown by a ritual ceremonial process that places these inhabitants of the heavenly realm in the real world. For this reason, the theory of Sundanese cosmology was used by researchers to analyze part of the structure of the performance of koromong art which is directly related to ritual-shaped processes. The community of Cikubang Village, Sukahayu Village, Rancakalong Subdistrict, Sumedang Regency, made this gamelan koromong art a distinctive art of the region. In the structure of its implementation, traditional art which consists of the art of gamelan music and dance is full of strict rules and karmic arrangements as a means of ritual. And these rules are still maintained up to now, even though in some aspects they have changed. These changes are the subject of this article.

\subsection{Gamelan koromong Art History}

Based on its historical history, the art of gamelan koromong is one of the traditional art forms in Cikubang Village (formerly called Cikebo which entered the Tanjungsari residency), Sukahayu Village, Rancakalong District, Sumedang District. According to the interview with the resource person, Haris (63 years), and Nandang (43 years) said that the gamelan koromong art in the Cikubang Rancakalong area had lived about 300 years ago, even this art has been passed down through the fifth generation (five epoch), led by Nandang. The links of the five generations are: (1) generation of Buyut Santing (the person who first initiated the gamelan koromong art in Cikubang Rancakalong); (2) the generation of the Eyang Uding (descendants of the great-grandfather Santing); (3) the generation of Ahud (son-in-law of Eyang Uding); (4) generation of Sukatya (son in law of Ahud) and (5) generation of Nandang (Sukatya's grandson). The heir of the last generation should have fallen to his son Sukatya, but because Sukatya did not have a son, his inheritance fell to his grandson, Nandang. (interview, January 25, 2019)

The first figure of the gamelan koromong Cikubang artist was Eyang Santing or Buyut Santing. He was the first person to know this art which at that time he received a set of gamelan. He received a message from someone to develop this art in his village, namely in Kampung Cikebo. Based on the results of interviews with Haris, the gamelan koromong was imported from the Banyumas area, namely the area in the Central Java Province. At that time the Cikebo village was experiencing a catastrophe due to inadequate agricultural yields for the lives of the Cikebo villagers. With this disaster, their agricultural products, especially rice, have experienced crop failures due to the attack of rice pests and due to bad weather, large winds which damage crops and heat causing drought. This situation lasted a long time and dragged on, so that the people of Cikebo were afflicted with misery, paré buhun of which they planted in the fields could not be obtained. Paré buhun is a type of high-stemmed rice plant (approximately $120 \mathrm{~cm}$ ) and is one of the staple foods of the people in the Cikebo area. 
Eyang Santing and several other community leaders immediately prepared the conditions for the ceremony to ward off the disaster that befell their farm. The ceremony was held on the night of the Sasaka Welas Opat which coincided with the night of the $14^{\text {th }}$ of Mulud. All the ceremonial requirements they prepare until the ceremony is carried out. After completing the ceremony, it was said that gradually all the disasters that had befallen agriculture in Cikebo Village gradually disappeared and the situation of agriculture returned to normal. They also enjoyed the agricultural produce they planted again. Since that time, the people of Cikebo Village each year when stepping on Sasaka Welas Opat, held a salvation ceremony by beating the gamelan koromong until now. Until the period of this research, the implementation of the koromong ceremony had taken five generations.

\subsection{The Gamelan koromong Art Context}

The main context of the Gamelan koromong is performed by the Cikubang community, which is a ritual and salvation function.

a. The ritual function is carried out every $14^{\text {th }}$ of Mulud. This village ritual program must be followed by all residents in Cikubang village. The event was like the beginning of the existence of gamelan koromong art which functioned as a village salvation event from disasters of plant pests and diseases. The ceremony is a mandatory thing to do and is followed by all residents so that they avoid the plague, especially in plant diseases. The place commonly used in performing gamelan koromong art is inside the house, which is a large house that can accommodate many people for ritual ceremonies. This is related to the ritual process, namely when lowering rice from goah which is a special place to store rice in the house.

b. Thanksgiving for the purpose of expressing gratitude to God. Besides being used in ritual ceremonies (on the $14^{\text {th }}$ of Mulud), gamelan koromong art can also be performed for other events, such as at home salvation events, sick salvation, baby birth salvation, etc. provided that the performance conditions are carried out as in mandatory ceremony. The place to carry out the show is in the homes of residents who have such rights.

\subsection{Change of Function}

In the present times as times change, gamelan koromong art that originally served as a ritual, is used for entertainment and salvation facilities or ruwatan. Residents of Cikubang Village or from outside can hold gamelan koromong art performances in their homes, provided that all ceremonial provisions and procedures must be adhered to carefully without being missed. The purpose can also vary, can be held to save the house, save the baby, save for sick people who have recovered, or just for entertainment that has a purpose.

The art of gamelan koromong in addition to having a ritual function, along with the development of the times also has other additional functions namely the function of entertainment and commercial functions. In the beginning, the structure of the show only focused on the ritual process, but now the structure of the show is increasing which ends with entertainment which shows more to popular culture. Changes do not only occur in the structure of the show, but in other cases there are also various changes in the repertoire of songs that use songs today in the post-independence of the Republic of Indonesia, the addition of musical instruments, changes in the costumes used, and changes on tools or equipment used for sesajen or offerings. In its development, gamelan koromong art experienced a change of 
function, which was used in thanksgiving and the salvation events at certain events such as circumcisions, salvation of sick people, and others.

\section{a. Ritual Function}

The ritual function in gamelan koromong art means of repelling reinforcements that disturbs the farming system in Cikubang village, especially rice plants. This ritual is also believed by the local community as a means of respecting the goddess of rice namely Dewi Sri or the local term call it Nyai Sri. This ritual activity is a tradition that must be carried out every year, namely the Sasaka Welas Opat which falls on the $14^{\text {th }}$ of Maulud. Towards this date, the entire population of Cikubang Village prepares all the requirements for the ceremony. Since the advent of the gamelan koromong until now, koromong performances have always been held. If it is not implemented, this is considered as a violation of habit which has been going on for generations, so that it will bring back catastrophe to their farming system. For this reason, every community living in Cikubang Village will immediately carry out the ritual on the $14^{\text {th }}$ of Maulud. They can provide anything for the smooth running of the ritual from the mind, energy, and even though.

b. Entertainment and Rescue Function

Nowadays, the gamelan koromong art originally functioned as a ritual only, used for entertainment and salvation facilities or ruwatan. Residents of Cikubang Village or from outside can hold gamelan koromong art performances in their homes, provided that all ceremonial provisions and procedures must be adhered to carefully without being missed. The purpose can also vary, can be held to save the house, save the baby, save for sick people who have recovered, or just for entertainment that has a purpose. The Cikubang community's trust in the ritual of koromong art is very strong. For example, when someone is sick, then this art is performed. After that, two or three days later the sick man recovered completely. Local people consider that with the spread of this art, means that they have fulfilled the pleasure of their ancestors. So that the ancestors will give reciprocity in accordance with the wishes of those who have the purpose. There is an event that considered a disaster, gamelan koromong art is usually performed in hopes of getting better things.

c. Commercial Function

In addition to having a ritual function, koromong art also has a commercial entertainment function. In fact, when there is one resident of Cikubang Village or from outside who wants to express this art, it must provide fees to the owner or management. According to them, for one show (one night) it can reach a price of between Rp. 1,000,000.00 to Rp. 1,500,000.00. This fee is indeed cheap for an art group, but they (administrators) say that such a price is enough for one show. They do not charge too much, enough for food and cigarette money for the players. The dedication to the gamelan koromong explains that the Cikubang people are not too concerned about profits even though they are commercial. Except for the mandatory event on the $14^{\text {th }}$ of Maulud, more expenses can be incurred. However, this can be overcome because in addition to being financed by the group cash, usually the entire Cikubang community conducts contributions, so that the high costs will be lighter because it is obtained from many people. In addition to money, usually people also donate other materials such as cooking utensils and others.

These changes in function ultimately change the other structures as well as in the increasing structure of the show. The process of transformation shows more new forms that are more adapted to the times. This means that the understanding of popular culture that took place in the modern century became an unavoidable thing in the area of traditional culture. So it can be concluded that the gamelan koromong art has undergone a process of transformation from ritual to popular forms. 


\section{Conclusion}

The context of gamelan koromong art is functioned as a medium to convey ritual objectives, which include rituals to prevent plant diseases and pests. In its development, gamelan music experienced a change in context in its function, which is used in thanksgiving, entertainment, and salvation events, such as circumcisions, the salvation of sick people, and others. This change in function changes the other parts of the textual and contextual gamelan arts. The main thing that triggers it is an adjustment to changing functions. In the end, it changes the existing structure even though the original structure still exists and is still used in every other ritual or performance. The shape of the new structure that is seen, is more likely to show the structure of a popular culture which shows more things that are modernized.

\section{Acknowledgment}

This research was funded by KEMENRISTEK DIKTI Republik Indonesia through Dissertation Doctoral Program (Program Desertasi Doktor) in 2019.

\section{References}

[1] Alam, Wd. Dharmawan Ider. (2008). Riwayat Hidup Raja-raja Sumedang Larang. Sumedang:Yayasan Pangeran Sumedang.

[2] Atmadibrata, Enoch. (1987). Proyek Penunjang Peningkatan Kebudayaan Propinsi Daerah Tk. I Jawa Barat. "Data Seni Pertunjukan Daerah Jawa Barat", dalam Kawit No. 41.

[3] Creswell, John. W. (2014), Penelitian Kualitatif \& Desain Riset. Yogyakarta: Pustaka Pelajar.

[4] Ernst. L, Heins. (1977). Goong Renteng: Aspect of Orchestral Music in Sundanese.Village. Amsterdam: Amsterdam Universitast Van Amsterdam.

[5] Giddens, A. (2010). Teori Strukturasi. Yogyakarta: Pustaka Pelajar.

[6] Heringa, Rens. (1997). Dewi Sri in Village Garb: Fertility, Myth, and Ritual in Northeast

[7] Java. Nanzan University. Jurnal (Asian Folklore Studies). Volume 56 (1997, 355-377) ISSN 0385-2342.

[8] Hill, Danise. (2011). The Practice and Social Evolution of the Javanese Gamelan:

[9] Evolution and Continuity. Contemporary Theatre Review, OPA (Overseas Publishers Association). Vol. 11, 2011 Part 1, p 19-27.

[10] Koentjaraningrat. (1987). Sejarah Teori Antropologi. Jakarta: UI Press.

[11] Kunst, Jaap. (1973). Music In Java. Jilid 2 edisi besar ke-3., ed. E.L.Heins. The Hague: Martinus Nighoff.

[12] Lihui, Yang. (2015). The Effectiveness and Limitations of "Context": Reflection Based on

[13] Ethnographic Researc of Myth Traditions. Nanzan University. Jurnal (Asian Ethnology). Volume 74 (2015, 363-377) ISSN 1882-6865.

[14] Rosidi, Ajip. (2000). Ensiklopedi Sunda "Alam, Manusia, dan Budaya termasuk Budaya Cirebon dan Betawi”. Jakarta: PT Dunia Pustaka Jaya.

[15] Rosidi, Ajip. (1970). Teori Dasar Karawitan. Bandung: PT Pelita masa.

[16] Sasaki, Mariko. (2007). Laras Pada Karawitan Sunda. Yogyakarta: P4ST UPI.

[17] Sumardjo, Jakob. (2006). Estetika Paradoks. Bandung: Sunan Ambu Press.

[18] Sumardjo, Jakob. (2001). Filsafat Seni. Bandung: Sunan Ambu Press.

[19] Suryalaga, Hidayat. (2009). Kasundaan, Rawayan Jati. Bandung: Divisi Penerbitan Yayasan Nur Hidayah.

[20] Suryalaga, Hidayat. (2010). Filsafat Sunda. Bandung: Divisi Penerbitan Yayasan Nur Hidayah. 
[21] Suwardi. (2013). Land Management, The Myth of Dewi Sri, and The Balance of

[22] Javanese Cosmology, an Anthropogeographic Overview. Faculty of Geography UGM and The Indonesian Geographers Association. Jurnal (Indonesian Journal of Geographic) IJG Vol. 45, No 2, December 2013 (158-170), ISSN 0024-9521.

[23] Wessing, Robert. (1990). Sri and Sedana and Sita and Rama: Myths of Fertility and

[24] Generation. Nanzan University. Jurnal (Asian Folklore Studies). Volume 49 (1990, 235-257) ISSN 0385-2342.

[25] Yudoyono, Bambang. (1984). Gamelan Jawa: Awal-Mula, Makna, dan Masa Depannya. Jakarta: Penerbit Karya Unipress. 